\title{
TESTING OF LOW-TEMPERATURE STABILIZATION ALTERNATIVES FOR SALT CONTAINING MIXED WASTES-APPROACH AND RESULTS TO DATE
}

Vincent Maio*

Lockheed Martin Idaho Technologies Co.

P.O. Box 1625

Idaho Falls, ID 8315

R. D. Spence

Oak Ridge National Laboratory**

P.O. Box 2008

Oak Ridge, TN 37831-6202

Gary Smith

Pacific Northwest National Laboratory

P.O. Box 999

Richland, WA 99352
R. K. Biyani

SGN Eurisys Services Corp.

P.O. Box 840

Richland, WA 99352

Guy Loomis

Lockheed Martin Idaho Technologies Co.

P.O. Box 1625

Idaho Falls, ID 83415

Arun Wagh.

Argonne National Laboratory

9700 S. Cass Avenue

Argonne, IL 60439
RECEIVED

JUN 102908

OSTI

Submitted for presentation at

Spectrum '98 International Conference

on Nuclear and Hazardous Waste Management

Denver, Colorado

September 13-18, 1998

\section{DISTRIBUTION OF THIS}

The submitted manuscript has been authored

by a contractor of the U.S. Government under contract No. DE-AC05-960R22464. Accordingly,

the U.S. Government retains a nonexclusive royalty-free license to publish or reproduce the published form of this contribution, or allow others to do so, for U.S. Government purposes.

*Author to whom correspondence should be addressed.

**Managed by Lockheed Martin Energy Research Corp. for the U.S. Department of Energy under contract DE-AC05-96OR22464. 


\section{DISCLAIMER}

This report was prepared as an account of work sponsored by an agency of the United States Government. Neither the United States Government nor any agency thereof, nor any of their employees, makes any warranty, express or implied, or assumes any legal liability or responsibility for the accuracy, completeness, or usefulness of any information, apparatus, product, or process disclosed, or represents that its use would not infringe privately owned rights. Reference herein to any specific commercial product, process, or service by trade name, trademark, manufacturer, or otherwise does not necessarily constitute or imply its endorsement, recommendation, or favoring by the United States Government or any agency thereof. The views and opinions of authors expressed herein do not necessarily state or reflect those of the United States Government or any agency thereof. 


\section{Testing of Low-Temperature Stabilization Alternatives for Salt Containing Mixed Wastes- Approach and Results to Date}

Vincent Maio

Lockheed Martin Idaho Technologies Co.

P.O. Box 1625

Idaho Falls, ID 83415

Guy Loomis

Lockheed Martin Idaho Technologies Co.

P.O. Box 1625

Idaho Falls, ID 83415
R.K. Biyani

SGN Eurisys Services Corp.

P.O. Box 840

Richland; WA 99352

Gary Smith

Pacific Northwest National Lab.

P.O. Box 999

Richland, WA 99352
Roger Spence

Oak Ridge National Lab.

P.O. Box 2000

Oak Ridge, TN 37831

Arun Wagh

Argonne National Lab.

9700 S. Cass Av.

Argonne, IL 60439

\section{ABSTRACT}

Through its annual process of identifying technology deficiencies associated with waste treatment, the Department of Energy's (DOE) Mixed Waste Focus Area (MWFA) determined that the former DOE weapons complex lacks efficient mixed waste stabilization technologies for salt containing wastes. These wastes were generated as sludge and solid effluents from various primary nuclear processes involving acids and metal finishing; and well over 10,000 cubic meters exist at 6 complex sites. In addition, future volumes of these problematic wastes will be produced as other mixed waste treatment methods such as incineration and melting are deployed.

The current method used to stabilize salt waste for compliant disposal is grouting with Portland cement. This method is inefficient since the highly soluble and reactive chloride, nitrate, and sulfate salts interfere with the hydration and setting processes associated with grouting. The inefficiency results from having to use low waste loadings to ensure a durable and leach resistant final waste form.

The approach for addressing this deficiency is based on system engineering principles dèveloped specifically for the MWFA' ${ }^{1}$. Based on these principles, requirements for resolution were identified and a technology development plan was prepared. The requirements, formulated with technical, regulatory, and stakeholder input, specify the performance levels expected for each salt waste stabilization process selected for development. The development plan documents the MWFA strategy for selecting and testing the various alternative stabilization technologies. The plan also defines the schedule and scope needed to ensure timely and cost effective delivery of adequate solutions to potential end users. Based on this strategy, the following five alternative salt waste stabilization technologies were selected for MWFA development funding in FY97 and FY98: 1.) Phosphate Bonded Ceramics, 2.) Sol-gel, 3.) Polysiloxane, 4.) Polyester Resin, and 5.) Enhanced Concrete.

Comparable evaluations were planned for the stabilization development efforts. Under these evaluations each technology stabilized the same type of salt waste surrogates as specified by the MWFA. Final waste form performance data such as compressive strength, waste loading, and leachability can then be equally compared to the requirements originally specified.

In addition to the selected test results provided in this paper, the performance of each alternative stabilization technology, will be documented in formal MWFA Technology Performance Reports (TPRs). These reports will provide the end users in the DOE complex the pertinent information necessary to select, through trade studies, the stabilization technology best suited for their salt waste applications.

\section{INTRODUCTION}

Significant technical deficiencies in the characterization, treatment, and disposal of DOE-complex mixed wastes (i.e., low-level radioactive wastes containing RCRA hazardous materials) were identified and prioritized for development funding during establishment of the 
Mixed Waste Focus Area (MWFA) Technical Baseline $^{2}$ in FY96 and FY97. These deficiencies, when resolved through technology development and demonstration efforts, will increase the mixed waste treatment capacities and capabilities of the DOE complex, decrease the amount of waste in inventory, and treat the waste in time to meet DOE commitments that have been established at various sites across the complex.

In particular, this document presents the MWFA development approach for the deficiency associated with stabilizing mixed wastes containing appreciable salt contents (concentrations of greater than $10 \%$ by weight). The approach adopted is based on the system engineering principles ${ }^{3}$ of problem and requirements definition, selection strategy development, and trade studies. In this paper, the salt waste stabilization deficiency is described in addition to the stabilization requirements needed for deficiency resolution. The technology selection strategy is then provided along with a brief description of each technology, its respective test program, and selected preliminary results to date.

\section{DEFICIENCY DESCRIPTION}

Systems engineering requires the formulation of a problem statement as the first step in any technical resolution. This section describes the current problem associated with salt waste stabilization.

Over the last 50 years of DOE operations, large quantities of mixed low-level wastes (MLLW) were generated from past nuclear weapons based industries and more recently from waste treatment processes. Stabilization has been and still is an effective, inexpensive, and simple treatment alternative for many types of these mixed wastes. This alternative is also accepted as safe and environmentally sound by both the regulators and the concerned public. A review of the technical literature and of past DOE operating experience shows that low temperature hydraulic cement, polymer, bitumen, and ceramic grout based stabilization methods produce waste forms that meet or exceed final disposal requirements ${ }^{4,5,6 .}$. The success level of the waste form is dependent on the original waste medium and the type and amount of hazardous and/or troublesome components in the untreated waste. Unfortunately, these current stabilization techniques have had limited success in accommodating homogeneous solid and sludge wastes containing relatively high concentrations of salts ${ }^{7}$ in addition to RCRA hazardous heavy metals

Salts (defined as the reaction product generated when a metal ion replaces the hydrogen ion of an acid) are highly soluble, easily hydrated, and reactive. As a consequence of these characteristics, low temperature stabilized forms of mixed low level wastes (MLLW) containing salts do not adequately cure or are susceptible to deterioration over time due to the expansion from the water-salt reaction. Salts interfere with the basic hydration reactions of cements and easily undergo dehydration/hydration cycles that can cause deteriorating expansions. This deterioration may lower the durability and strength of the stabilized waste form and create pathways for the hazardous and radiological constituents to be released from the immobilized waste.

In some cases, leach resistant salt waste forms of sufficient durability are possible with the current stabilization techniques. However, these techniques usually result in forms with excessive increases in waste volume due to low waste loadings. Basic Portland cement formulations can only accommodate $\sim 15 \mathrm{wt} \%$ of salts. These process inefficiencies and subsequent high disposal costs offset any benefits. The limitations of these current methods are of immediate concern since future volumes of salt wastes are anticipated as other MLLW treatment processes are implemented. Future effluents from MLLW wastewater treatment systems and scrubber blowdown from future and present MLLW thermal systems (i.e., incinerators and melters) will significantly add to the MLLW salt inventory.

\section{REQUIREMENTS FOR DEFICIENCY RESOLUTION}

Another concept of systems engineering is that a set of end product requirements must be specified prior to initiating development of solutions. Table I contains a summarized list of the key requirements pertinent for stabilized 
forms of salt waste. The list was extracted from a MWFA prepared requirements document completed specifically for the salt waste stabilization deficiency.

The requirements of Table I mirror many of those specified by the NRC Technical Position Paper for stabilized low-level radioactive waste forms ${ }^{8}$. The requirements of this position paper pertaining to allowable free liquid amounts, biodegradation, radiation stability, and chemical durability have been omitted at this time to minimize the waste performance testing burden imposed on the developers without compromising the amount of information needed to ensure an adequate final waste form during the initial development phase.

In addition to the technical criteria listed in Table I, the Requirements Document contains other criteria that are to be used for comparing developing stabilization technologies if the technologies rate equal with regard to the criteria above. These criteria include standards for complexity of operation, robustness of process, equipment availability, secondary waste generation, through-put potential, scale of proven process, ease of permitting, and public acceptance. Because most stabilization processes have traditionally rated well against these criteria, they will not be utilized as primary criteria for assessing the stabilization technologies unless they are considered pertinent by a specific end user.

Cost will be indirectly considered as a criterion even though it is difficult to estimate during the development phase and these estimates are highly sensitive to any changes in assumptions. Low temperature stabilization methods have already been proven to be cost effective MLLW treatment alternatives in many cases. Operating experience indicates that for these methods, volume dependent costs such as packaging, shipping, and disposal of the final waste form are far greater than the actual stabilization process. As such, savings are usually the result of increasing waste loadings or decreasing the final waste volume. These two key requirements are easily correlated directly to cost and will be considered as is shown in Table I.

It is imperative that any development effort initiated to resolve specific deficiencies ensures the collection of test data necessary for determining compliance with the requirements. As such, the investigators for each stabilization development effort were required to submit, for MWFA approval, test plans describing the experimental protocol and data to be collected. In all cases investigators were given enough resources to determine, as a minimum, waste form strength, leachability, and waste loading.

\section{SELECTION STRATEGY FOR TECHNOLOGY DEVELOPMENT}

Predefining the boundaries of an activity through strategy development is a systems engineering technique employed to streamline a process and focus on the defined problem. To ensure that MWFA funds are used in a costeffective manner, the following strategies were established for selecting the development activities and defining their respective test programs.

A. Scope Strategy The development efforts are to focus only on enhanced or alternative stabilization techniques that meet or exceed basic disposal requirements and lower costs by decreasing volumes, increasing waste loadings, and enhancing operability. Based on their probable higher cost, longer development time, lower stakeholder acceptance, greater generation of secondary wastes, and the amount of additives necessary, vitrification of salt waste or salt separation technologies have been eliminated from consideration. The development efforts must also build on past successful achievements and operating experiences with currently available stabilization techniques (i.e. hydraulic cement). These techniques already have a proven track record in meeting basic disposal requirements, being cost effective and simple, and achieving stakeholder acceptance.

Development efforts that enhance these current techniques for salt wastes by accommodating higher waste loadings with lower net volume increases are low risk approaches that have a high probability of resolving this deficiency.

B. Schedule Strategy Individual development elements are to be structured to maximize the probability of successfully resolving the deficiencies within two to three years. This time limitation was imposed to ensure that stabilization alternatives are available concurrent 
with the earliest start-up dates of the new MLLW treatment facilities that will produce salt containing wastes. This limitation is based on actual waste treatment deadlines and start-up dates for planned DOE treatment facilities as documented in published Site Treatment Plans (STPs). These STPs result in legally binding agreements established between the DOE and an environmental regulatory agency, and provide the strongest driver for resolving the deficiencies in a given amount of time. The two to three year time frames are to be considered a maximum target date, and every effort shall be made to accelerate each development activity to support up-coming privatization efforts.

C. Test Program Strategy The development efforts are to test all stabilization technologies with the same waste surrogate composition. These surrogate wastes must also represent the majority of the current and predicted future salt containing inventories. For salt, this waste type is wet and dry homogeneous solids and sludges containing primarily nitrate, chloride and sulfate salts. The nitrate and chloride salts of sodium and potassium are of key concern due to their abundance, high solubility and high reactivity. The volumes of MLLW that contain other salts such as carbonates and/or fluorides are not significant enough to warrant specific development funding at this time.

\section{TECHNOLOGIES SELECTED AND TEST PROGRAMS}

To facilitate trade studies by potential end users, systems engineering requires the development of alternatives.

Alternative stabilization technologies chosen for development testing on salt wastes are described below. They were selected after a MWFA call for proposals specifically for salt stabilization waste technologies and were chosen based in part on their potential to meet the requirements and criteria presented in this paper.

1. Chemically Bonded Phosphate Ceramics (CBPC): A ceramic based low- temperature stabilization process developed by Argonne National Laboratory, ANL-E. The process has been successfully demonstrated with surrogates and actual mixed waste soils, bottom ash and wastewater at the bench, pilot, 5-gallon, and 55-gallon scale. Current demonstrations are also planned for small debris and Pu-contaminated ash. The process involves the acid-base reaction of phosphoric acid or monopotassium phosphate with magnesium oxide. This process creates insoluble phosphates of the RCRA hazardous metals and radiological components and creates a physical ceramic barrier to leaching. The process is simple, has shown good final waste form durability, nonleachability, efficient compression strength, generates little heat, and uses offthe shelf equipment

2. Sol-gel Techniques: Sol-gel is the general scientific term given to processes that start as a mixture of liquid solutions, that subsequently solidify or gel into a 3-D solid form upon reacting at low temperature. Investigators at the University of Arizona, via a contract through Pacific Northwest National Laboratories, are developing various Sol-gel processes that will microencapsulate the salt surrogates after their addition to the base sol-gel solutions. Inorganic (ceramic), organic (polymer), and inorganic-organic combinations (polycerams) are being formulated and tested as base Sol-gel systems. Results to date indicate that the poly-cerams are most effective for stabilization of the salt containing mixed waste surrogates.

3. Polysiloxane: The polysiloxane process is a thermosetting polymeric process, whereby the waste and the polysiloxane base monomer of silicon dioxide are added together in the presence of a platinum catalyst. A private company developed the method and testing was done in conjunction with scientists at the INEEL. To date testing with the MWFA surrogate waste recipes is complete and results are encouraging.

4. Polyester: This Hanford development effort focuses on the testing of four types of commercially available polyester resins for both wet and dry salt wastes. A statistical test program was established to determine the effects of waste loading and initiator amounts on waste form performance and cure time. Successful testing of the standard MWFA surrogates have been completed and 
treatability studies on an actual Hanford waste stream is in progress.

5. Enhanced Concrete Grouting: The development of enhanced salt waste stabilization techniques involving Portland cement grouting are advantageous in that DOE end users are already familiar with the processes, and the enhanced methods will be compatible with existing grout equipment. Through a contract with developers at Oak Ridge National Laboratories, methods are being investigated to increase the salt waste loading in various test matrices of cementitious materials. An array of statistical tests is being completed. In these tests the stabilizers are added to salt waste surrogates containing varying amounts of nitrates, chlorides, and sulfates. The standard MWFA surrogate composition is included in the array to facilitate equal comparison to the other four processes.

As previously indicated, the salt waste stabilization techniques will be equitably compared based on their performance after stabilizing two types of standard waste surrogates. One of the surrogates represents the majority of previously grouted dry solids in the complex and contains a high level of nitrates. The other surrogate waste contains both chlorides and sulfates and represents an unconcentrated blowdown from an incinerator or thermal unit. Both surrogates contain RCRA heavy metals in the 1000 ppm range, thus providing a challenge to the stabilization technique. The inerts of the surrogates are mostly oxides and hydroxides. Table II provides the detailed compositions of the MWFA specified surrogates.

\section{RESULTS}

1. All of the 5 salt stabilization alternative technologies have been tested with the two standard MWFA surrogates and the majority of the waste form performance date is available as indicated in the selected results provided in Table III. To date, complete results are available for the polysiloxane, polyester and enhanced concrete test programs and final results for the remaining two will be available in late May. It is important to note that the selected results reported are only a sample of the performance data available for the waste forms prepared with the 5 technologies chosen for testing. No attempt has been made to rank or rate the technologies on a distinct parameter, such as waste loading, since end users and waste owners have different criteria for each of their unique waste management problems. In some cases factors such as waste volume, and equipment availability may have a greater impact on the selection of a stabilization alternative then either waste loading or volume reduction.

In addition to conducting tests with the MWFA salt surrogates, additional evaluations were performed to further define the boundaries of each of the five technologies. For example both the enhanced concrete and polysiloxane technologies were used to stabilize and test the performance of surrogates representing actual salt mixed waste inventories at Oak Ridge and the Idaho National Engineering and Environmental Laboratory. In addition the polyester process tested an actual Hanford mixed waste under a treatability study. Both the enhanced concrete and polyester technologies also tested surrogate wastes with higher salt loadings then provided by the MWFA surrogates. Results are available in the referenced documents.

\section{CONCLUSION}

Systems engineering principles have proven to be effective in addressing complex technical problems and are applicable for the resolution of mixed waste treatment deficiencies identified in the DOE complex. These systems engineering techniques include precise problem definition, requirement identification, selection strategy development, and the generation of alternatives data to complete trade studies. In particular use of these principles has led to the establishment of an end user based development program for resolving the MWFA identified deficiencies associated with stabilizing salt containing mixed waste.

Data collected upon completion of the fiveway salt waste stabilization development effort will be formally documented in MWFA Technology Development Reports (TPR) by the end of FY98. The TPRs will assess each stabilized waste form's performance against the requirements and provide data for trade studies 
by potential end users of the developed methods. End users in the DOE complex will then have a method to assist them in selecting stabilization technologies to best fit their salt containing waste treatment needs.

\section{ACKNOWLEDGEMENTS}

All of this research and development on salt stabilization alternatives is sponsored by the DOE's Office of Science and Technology, Mixed Waste Focus Area.

\section{REFERENCES}

1. Beital, G. A., Systems Engineering Identification and Control of Mixed Waste

Technology Development, Journal of Franklin Institute, Vol. 334A, Issue 2-6, 1997.

2. Mixed Waste Focus Area Integrated Technical Baseline Report, Phase 2, Volumes 1and 2, DOE/ID- 10524, Revision 1, Idaho National Engineering and Environmental Laboratory, Idaho Falls, ID, April 1997.

3. Martin, James N. Systems Engineering Guidebook-A Process for Developing Systems and Products, Chapter 2, CRC Press, 1997.

4. Kalb, P. D., Conner, J. R., Mayberry, J. L., Patel, B. R., Perez, J. M., Treat, R. L.,

5. Stabilization/Solidification -Innovative Site Remediation Technology-Design and Application, WASTECH and The American Academy of Environmental Engineers, 1997.

6. Moghissi, A. A., Godbee, H. W., Hobart, S. A., Radioactive Waste Technology, Chapter 8 , The American Society of Mechanical Engineers, 1986.

7. Stabilization/Solidification Processes for Mixed Wastes, United States Environmental

: Protection Agency, EPA 402-R-96-014, June 1996.

8. Bleier, A. Evaluation of Final Waste Forms and Recommendations for Baseline Alternatives to Grout and Glass, ORNL/TN13214, DOE-Oak Ridge National Laboratory, September 1997.

9. Stabilization/Solidification of CERCLA and RCRA Wastes-Technical Position on Waste Form, Revision 1, USNRC, January 1991.
10. Spence R.D., Burgess M.W. Cementitious Stabilization with High Salt Loadings, draft report, DOE-Oak Ridge National Laboratory, March 1998.

11. Biyani R.D. Report on Microencapsulation of Surrogate Salt Wastes with Polyester Resins, SESC-EN-RPT-017, Rev.0, SESCHanford, November 1997.

12. Loomis G.G., Miller C.M., Prewett S.W., Mixed Waste Salt Encapsulation Using Polysiloxane-Final Report, INEEL/EXT-9701234, Idaho National Engineering and Environmental Laboratory, November 1997. 
TABLE I: KEY REQUIREMENTS FOR SALT-CONTAINING WASTE AND ASH STABILIZATION

\begin{tabular}{|c|c|}
\hline REQUIREMENT & REQUIREMENT LEVEL \\
\hline \multicolumn{2}{|l|}{ Basic Disposal Criteria } \\
\hline Structure/Particle Size of the Final Waste Form & $\begin{array}{l}\text { The final waste form must be monolithic in structure for both } \\
\text { cement and non-cement stabilization methods. }\end{array}$ \\
\hline $\begin{array}{l}\text { Strength of the Final Waste Form (As Measured as the } \\
\text { Unconfined Compressive Strength/UCS ) }\end{array}$ & $\begin{array}{l}\text { In accordance with (IAW) The American Society for Testing } \\
\text { and Materials (ASTM) Standards C } 39 \text { or D695: The final waste } \\
\text { form must have a UCS of at least } 500 \text { psi for cement based } \\
\text { methods and } 60 \text { psi for non-cement methods. }\end{array}$ \\
\hline $\begin{array}{l}\text { Leachability of the Final Waste Form as Measured by the } \\
\text { EPA/RCRA Established TCLP Test for Toxic/Hazardous } \\
\text { Metals }\end{array}$ & $\begin{array}{l}\text { The final waste form must meet RCRA Land Disposal } \\
\text { Requirement (LDR) standards for leachability as determined by } \\
\text { the Toxic Characteristic Leaching Procedure (TCLP). Proposed } \\
\text { (as opposed to the present Universal Treatment Standards/ UTS) } \\
\text { levels are to be used. }\end{array}$ \\
\hline Chemical Durability of the Final Waste Form & $\begin{array}{l}\text { IAW ANS 16.1: For cement based stabilization methods, the } \\
\text { final waste form must have a Leachability Index (LI) value of at } \\
\text { least } 6.0 \text { and retain its original UCS five days after the LI test. } \\
\text { The same holds for non-cement forms, except the UCS retention } \\
\text { must be for } 90 \text { days. }\end{array}$ \\
\hline $\begin{array}{l}\text { Final Waste Form Resistance to Thermal } \\
\text { Degradation and Cycling }\end{array}$ & $\begin{array}{l}\text { IAW ASTM B553: The final waste form must maintain an UCS } \\
\text { of at least } 60 \text {-psi after } 30 \text { thermal cycles; a cement waste form } \\
\text { must also show no sign of cracking, spalling, or disintegration. }\end{array}$ \\
\hline \multicolumn{2}{|l|}{ Enhancement Criteria } \\
\hline $\begin{array}{l}\text { Waste Loading as a Percentage of the Final Waste Form that } \\
\text { Comprises the Original Waste }\end{array}$ & $\begin{array}{l}50 \% \text { by weight. The waste loading must be calculated based on } \\
\text { the waste in its original " as received "condition. The total } \\
\text { weight of the waste prior to any pretreatment (such as the } \\
\text { evaporation of any liquids) is to be used. }\end{array}$ \\
\hline
\end{tabular}

\section{TABLE II STANDARD MWFA SALT SURROGATE COMPOSITIONS}

\begin{tabular}{|c|c|c|}
\hline Constituent & $\begin{array}{c}\text { High Chloride } \\
\text { wt.\% }\end{array}$ & $\begin{array}{c}\text { High Nitrate } \\
\text { wt. } \%\end{array}$ \\
\hline$\overline{\mathrm{Fe}}(\mathrm{OH})_{3}$ as $\mathrm{Fe}_{2} \mathrm{O}_{3}$ & 12.75 & 6.0 \\
\hline $\mathrm{Al}_{2}(\mathrm{OH})_{3}$ & 8.5 & 4.0 \\
\hline $\mathrm{Na}_{2} \mathrm{PO}_{4}$ & 4.25 & 2.0 \\
\hline $\mathrm{Mg}(\mathrm{OH})_{2}$ & 8.5 & 4.0 \\
\hline MicroCel E & 17.0 & 8.0 \\
\hline Portland Cement (Type II) & 4.25 & 2.0 \\
\hline $\mathrm{H}_{2} \mathrm{O}$ & 29.75 & 14.0 \\
\hline \multicolumn{3}{|l|}{ Salts } \\
\hline $\mathrm{NaCl}$ & 10.0 & 0.0 \\
\hline $\mathrm{CaSO}_{4}$ & 5.0 & 0.0 \\
\hline $\mathrm{NaNO}_{3}$ & 0.0 & 60.0 \\
\hline Contaminants & $\mathrm{mg} / \mathrm{kg}$ & $\mathrm{mg} / \mathrm{kg}$ \\
\hline \multicolumn{3}{|l|}{ Toxic Metal Oxides $^{3}$} \\
\hline $\mathrm{PbO}$ & 1000 & 1000 \\
\hline $\mathrm{CrO}_{3}$ & 1000 & 1000 \\
\hline $\mathrm{HgO}$ & 1000 & 1000 \\
\hline $\mathrm{CdO}$ & 1000 & 1000 \\
\hline $\mathrm{NiO}$ & 1000 & 1000 \\
\hline Trichloroethylene ${ }^{4}$ & 1000 & 1000 \\
\hline Total & 100.0 & 100.0 \\
\hline
\end{tabular}


Table III Selected Salt Waste Stabilization Results and Waste Performance Data with MWFA Surrogates

\begin{tabular}{|c|c|c|c|c|c|}
\hline $\begin{array}{l}\text { Waste Form } \\
\text { Performance } \\
\text { Measure }\end{array}$ & $\begin{array}{c}\text { Waste } \\
\text { Loading } \\
\text { wt } \%\end{array}$ & $\begin{array}{l}\text { Salt Loading } \\
\text { wt } \%\end{array}$ & $\begin{array}{c}\text { Compressive Strength } \\
\text { psi }\end{array}$ & $\begin{array}{l}\text { Leachability } \\
\text { TCLP }\end{array}$ & $\begin{array}{c}\text { Leachabilit } \\
\text { y } \\
\text { ANSI } 16.1 \\
\text { index }\end{array}$ \\
\hline Surrogate Type & $\mathrm{NO}_{3} / \mathrm{Cl}$ & $\mathrm{NO}_{3} / \mathrm{Cl}$ & $\mathrm{NO}_{3} / \mathrm{Cl}$ & $\mathrm{NO}_{3} / \mathrm{Cl}$ & $\mathrm{NO}_{3} / \mathrm{Cl}$ \\
\hline \multicolumn{6}{|l|}{ Technology } \\
\hline $\begin{array}{l}\text { Enhanced } \\
\text { Concrete }^{10}\end{array}$ & $69 / 55$ & $36.3 / 8.2$ & $1032 / 535$ & $\begin{array}{l}\text { Passed for } \mathrm{Cd}, \mathrm{Cr} \text {, } \\
\mathrm{Ni} \text {, and } \mathrm{Pb}\end{array}$ & NA \\
\hline $\begin{array}{l}\text { Polyester ( vinyl } \\
\text { ester resin only) }\end{array}$ & $50 / 50$ & $30 / 7.5$ & $6200 / 5100$ & $\begin{array}{c}\text { Passed for } \mathrm{Cr}, \mathrm{Pb} \text {, } \\
\mathrm{Hg}\end{array}$ & $\begin{array}{c}7.7 / 7.6 \\
\text { for } \mathrm{Na} \text { ions }\end{array}$ \\
\hline Polysiloxane $^{12}$ & $50 / 50$ & $30 / 7.5$ & $420 />637$ & $\begin{array}{c}\text { Passed for } \mathrm{Cd}, \mathrm{Cr} \text {, } \\
\mathrm{Hg}\end{array}$ & NA \\
\hline $\begin{array}{l}\text { Phosphate Bonded } \\
\text { Ceramics }\end{array}$ & $70 / 68$ & $42 / 11$ & NA & $\begin{array}{l}\text { Passed for } \mathrm{Cd}, \mathrm{Cr} \text {, } \\
\mathrm{Pb}, \mathrm{Hg}, \mathrm{Ni}\end{array}$ & $\begin{array}{l}7.1 \text { for } \mathrm{Cl} \\
9.0 \text { for } \mathrm{NO}_{3} \\
\end{array}$ \\
\hline Sol-gel & $70 / 60$ & $43.5 / 11.5$ & $1513 / 1050$ & $\begin{array}{l}\text { Preliminary } \\
\text { results are not } \\
\text { conclusive }\end{array}$ & $\begin{array}{c}7.6 / 7.5 \\
\text { for } \mathrm{Na} \text { ions }\end{array}$ \\
\hline & & & & & \\
\hline
\end{tabular}



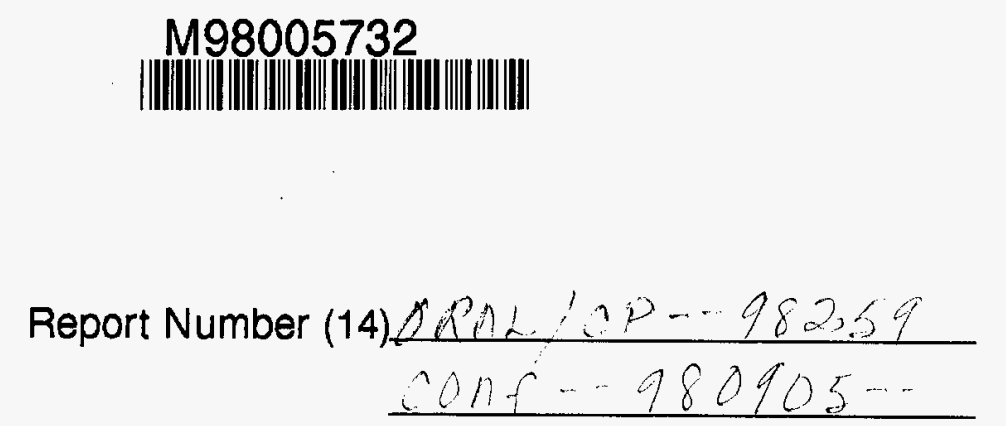

Publ. Date (11) $1,50 S$
Sponsor Code (18) DOE/EM, XF
UC Category (19) UC-2000, DOE/ER 